\title{
STANDARDS OF PATENTABLE INVENTION FROM 1474 TO 1952
}

\author{
Frank D. PRAGER*
}

I T IS BASIC IN AMERICAN THOUGHT that monopolies are harmful and illegal, but there are some exceptions from this rule, including mainly the patent: a monopoly right, limited in time, which covers and protects an "invention."

Patent monopolies are proper when secured to "Inventors" for their respective "Discoveries." This is stated unequivocally in the Constitution, Article I, Section 8. On this basis our statutes say that a patent presupposes an "invention or discovery," which must be new ${ }^{2}$ and must moreover "appear sufficiently useful and important."3

In view of this emphatic, if not too specific law, our judges and patent examiners agree that "invention," in addition to plain novelty and utility, is one of the important prerequisites of a valid patent. ${ }^{4}$ Decisions denying this rule have been announced but rarely. ${ }^{5}$ However, there is hot debate about the meaning of "invention"; and here, some of our judges and patent examiners disagree widely. The present majority of the Supreme Court holds, under the guidance of Justices Black and Douglas, that the Patent Office uses too low a standard of patentable invention, thereby aiding and abetting the creation of harmful and illegal monopolies. ${ }^{6}$ Justices Frankfurter and Jackson dissent sharply; in fact they apply standards considerably lower than those of the Patent Office. ${ }^{7}$ For the Office itself the Court of Customs and Patent Appeals has the final word. It has roundly refused to follow the Supreme Court's view. Similarly that view has been "rejected" by the Seventh Circuit Court of Appeals. It has been accepted by

* Instructor on Patents, Illinois Institute of Technology and Member of the Illinois Bar.

146 Stat. 376 (1930), 35 U.S.C.A. $\$ 40$ (1947).

253 Stat. 1212 (1939), 35 U.S.C.A. $\$ 31$ (1947).

316 Stat. 202 (1870), as amended, 35 U.S.C.A. $\$ 36$ (1947).

"See, e.g., I Robinson, Law of Patents 111 (1890); Stedman, Patents 86 (1939).

5 "That the advance is inventive is equally clear to me, because it is new." Jungersen $v$. Morris Kaysen Co., 31 F. Supp. 703, 706 (E.D. Pa., 1940).

- In Great A. \& P. Tea Co. v. Supermarket Corp., 340 U.S. 147, 154 (1950) the Court said, "a standard of invention appears to have been used that is less exacting than that required." The concurring opinion of Justice Douglas, joined by Justice Black, speaks of the "spawning" of "incredible" patents by the Patent Office.

7 E.g., Jungersen v. Ostby \& Barton Co., 335 U.S. 560 (1949); Marconi Wireless Co. v. United States, 320 U.S. 1 (1943). 
the Second Circuit Court of Appeals, but only with "caution." These announcements of noncompliance or only partial compliance, ${ }^{8}$ concerning a legal and constitutional question, indicate that something is drastically wrong somewhere. The problem can hardly be dismissed with the philosophical observation that it is hard or impossible to define the concept in question. ${ }^{9}$

Rather, it seems necessary to analyze the problem historically and systematically. Even in a historic study of the matter we are immediately faced with a very debatable issue.

\section{The Eariy Background for Patent Standards-1474 to 1789}

It has been claimed that the requirement of invention is a mere product of judicial legislation, starting about 1850 . This view has been expounded in England as early as 1899 and has recently been urged in this country and Canada, mainly in articles by Drury W. Cooper and a book by Harold G. Fox. These writers claim that a patent requires nothing beyond plain novelty and utility. ${ }^{10}$

Some followers of this belief would even revise current standards of novelty, and allow re-patenting so long as a patented design has not actually been manufactured and sold. This proposal has been made under the heading "Back to Queen Elizabeth." Such views are rare, but the underlying historic theory is widely accepted. It is accepted even by writers who deplore the economic consequences. ${ }^{12}$ As we will see, the theory has gained influence on legislative proposals for a revision of the patent system.

The two main items of evidence adduced by Cooper and Fox are: First, the English legal practice of the 15th, 16th and 17th centuries used the words "inventor" and "importer" interchangeably in many instances;"13 Second, in the American Constitution and in the patent statutes of 1790 and 1836, nothing was said about any particular standard of invention. ${ }^{14}$

These facts are undeniable, but they do not justify the theory that has

${ }^{8}$ In re Shortell, 142 F. 2d 292 (Cust. \& Pat. App., 1944); Chicago Steel Foundry Co, v. Burnside Steel Foundry Co., 132 F. 2d 812 (C.A. 7th, 1943); Picard v. United Aircraft Corp., 128 F. 2 d 632 (C.A. 2d, 1942).

9 E.g., McClain v. Ortmayer, 141 U.S. 419 (1896), a case involving a horse collar patent.

${ }^{10}$ Cooper, Some Ghosts of the Law, 23 J. Pat. Off. Soc. 319 (1941); Cooper, Patent Law; Challenging the Courts' View of "Invention," 35 A.B.A.J. 306 (1949); Fox, Monopolies and Patents (1947); Daniell, Inventions and Invention, 11 Jurid. Rev. 151 (1899).

11 Vojacek, Back to Queen Elizabeth, 32 J. Pat. Off. Soc. 629 (1950).

12 E.g., Stedman, Invention and Public Policy, 12 Law \& Contemp. Prob. 649, 670 (1947); Derenberg, Review of Fox, Monopolies and Patents, 29 J. Pat. Off. Soc. 693 (1947).

${ }^{13}$ See also Hulme, History of the Patent Law, 18 L.Q. Rev. 280 (1902); Daniell, op. cit. supra note 10.

${ }^{14}$ See also Federico, The Concept of Patentable Invention, 32 J. Pat. Off. Soc. 118 (1950). 
been based on them. That early English practice identified importers with inventors does not show any lack of interest in the merits of the items invented or imported. It only shows that, before the advent of technical instruction in print, disclosure of new technology required actual commercial introduction and use. All cases where a man, by invention or commercial enterprise, was able to "bring any new trade into the realm" were considered proper cases for a patent monopoly, but only if it was "for the good of the realm." These expressions were used in Darcy v. Allin, the famous "Case of Monopolies," 1602.15

Further, that the American statutes require "new and useful invention" justifies no disregard of the noun "invention" and exclusive reliance on the adjectives "new and useful." The Constitution, as mentioned, requires "discoveries" of "inventors."

Further, there is strong direct evidence against the theory of Cooper and Fox. As early as 1474 it was said in a patent statute, enacted by the Republic of Venice, that a patent is proper in the case of a new "and ingenious" device. ${ }^{16}$ The wording of this law was rediscovered recently. For a long time it has been known that the Venetian law was influential in the development of the English patent system. ${ }^{17}$

Wherever it may have originated, the requirement of inventive merit was clearly established under Queen Elizabeth, and was merely disregarded by corrupt courtiers and officers. A case in point is that of Matthey's patent for a certain type of knife handles. This was cited by counsel for the defense in the Case of Monopolies, and is also known from separate historic research. ${ }^{18}$ The patent was issued in 1571 . It was immediately opposed by the cutlers' gild in a kind of invalidity procedure. We read that the company of cutlers did show before some of the Counsel and some learned in the law that they did use to make knives before, though not with such hafts, that such a light difference or invention should be no cause to restrain them; whereupon he could never have benefit of his patent although he labored very greatly therein.

${ }^{15}$ Noy Report 173, 182 (1669); 1 Web. Pat. Cas. 1 (1844), also reprinted in part in I Robinson, Law of Patents 10 (1890). The famous expression occurs in the argument of counsel: "[W] here any man by his own charge and industry, or by his own wit and invention, doth bring any new trade into the realm, or any engine tending to the furtherance of a trade, that never was used before,- and that for the good of the realm-that in such cases the king may grant him a monopoly patent for some reasonable time, until the subjects may learn the same, in consideration of the good that he doth bring by his invention to the Commonwealth; otherwise not."

${ }^{16}$ Mandich, Venetian Patents, 30 J. Pat. Off. Soc. 166, 177 (1948).

${ }^{17}$ Ibid., at 205, 206; Hulme, History of the Patent System, 12 L.Q. Rev. 141 (1896); Gomme, Patents for Inventions 8 (1946); Doorman, Patents for Inventions in the Netherlands, 14, 15 (1942).

${ }^{18}$ Cited in Hulme, History of the Patent System, 16 L.Q. Rev. 44, 45 (1900), and Darcy v. Allin, op. cit. supra note 15 . 
The terminology as to "invention" was old-fashioned but the tenor was modern; the patent was invalidated for lack of inventive merit.

Very similar was the case of Hastings' patent for a certain kind of cloth, issued in $1569 . .^{19}$ The patent application had been supported by a gild. An attempt was then made to enforce it against another gild. The suit was dismissed when the defendants showed that they had previously made cloth "very like to" that of the patent.

Further decisions to the same effect are known from subsequent English records. ${ }^{20}$ Most important was the case of Bircot's patent, reported with approval in the Institutes of Sir Edward Coke, which were published shortly after 1600 . In this case a patent for a new smelting method was invalidated. It was said

that that was but to put a new button to an old coat, and it is much easier to add than to invent.21

The modern use of the word "invent" should be noted.

Under the influence of this case, English courts were long inclined to invalidate patents for "mere" improvements and to uphold a patent only if it disclosed a more or less basic "manufacture," either newly invented or newly imported. This tendency, which was much stricter than the continental one, ${ }^{22}$ prevailed until Morris v. Bransom in $1776 .{ }^{23}$ In that case, Lord Mansfield adopted more lenient rules on the validity of patents; and such rules were upheld by his successors. However, even after that relaxation, a great number of English patents were invalidated for lack of inventive merits. ${ }^{24}$

A peculiar feature of the English patent system, then and later, was that noninventiveness was a ground for invalidity of a patent, but was not a ground for rejection of a patent application. This system was in effect until 1949; even then it was clarified only in part. During and after the application stage, noninventiveness is considered only when urged by a third party, not upon the English magistrate's own motion..$^{25}$

${ }^{19}$ Cited in Hulme, History of the Patent System, 12 L.Q. Rev. 141, 149-50 (1896), and Darcy v. Allin, op. cit. supra note 15.

${ }^{20}$ Hulme, Privy Council Patent Law, 33 L.Q. Rev. 67, 180 (1917).

211 Web. Pat. Cas. 31 n.(p) (1844).

22 Mandich, op.cit. supra note 16, at 177; Hoffmann, Zeitschrift fuer Industrie-Recht 115, 116 (1915); Doorman, op. cit. supra note 17, at 93-100.

${ }^{23} 1$ Web. Pat. Cas. 51 (1844). Hulme, op. cit. supra note 13, at 282-83 and note 20, at 67. The year 1776 was notable also because of the extension of James Watt's first steam engine patent; see Smiles, Life of Watt 175-81 (1904). Smiles speaks of 1775 (old style).

${ }^{24}$ See, e.g., King v. Else (1785), 1 Web. Pat. Cas. 75, 205, 208 (1844).

25 Patents and Designs Act, Great Britain Stat. (1949) $\$ 14$ (1): "Any person interested may give notice ... of opposition on ... the following grounds: ... (e) that the invention, so 
It must further be noted that, while the substantive requirement of inventiveness was maintained in principle, it was further relaxed by certain English court decisions. Most important in this respect was the growth of the doctrine that inventiveness resides in, or can be shown by, the production of a "new and beneficial result." During and after the Industrial Revolution this principle was applied; first with doubts and dissents, later with strength and insistence. ${ }^{26}$

\section{Patent Standards duRING the Formation of the American Patent System-1790 ro 1853}

During the first, formative sixty years of the American patent system, both administrative and judicial views on inventiveness were rather different from those announced in the English practice of the time.

The first American patent statute was enacted in $1790 .{ }^{27}$ It delegated the congressional patent power to certain cabinet officers; practically to Thomas Jefferson. Certain working rules were immediately adopted by or under Jefferson. According to his informal summary, written later on: One of these rules was that a machine of which we were possessed might be applied by every man to any use of which it was susceptible. . . Another rule was that a change of material should not give title to a patent. . . A third was that the mere change of form should give no right to a patent. ${ }^{28}$

He knew that these rules required "maturing." It should be noted that while the requirement of inventiveness was old, these were the first detailed rules about it, announced anywhere, aside from the new result principle which simultaneously grew up in England.

In 1793 Congress adopted one of these administrative rules, the third one, in slightly amplified form. The new act stated in Section 2:

[S]imply changing the form or the proportion of any machine or composition of maiter, in any degree, shall not be deemed a discovery. (Emphasis added.) ${ }^{29}$

All these are now known as "negative rules," as compared with the "positive rule" referring to new results.

The positive or new result rule was not only disregarded by Jefferson; it

far as claimed in any claim of the complete specification is obvious and does not involve any inventive step having regard to matter published ... or having regard to what was used in the United Kingdom before the priority date of the applicant's claim."

${ }^{2}$ Boulton v. Bull, 2 Black 463 (1795), also cited in LeRoy v. Tatham, 14 How. (U.S.) 155, 182 (1852); Crane v. Price (1842), 1 Web. Pat. Cas. 375 (1844).

271 Stat. 109 (1790).

${ }^{28}$ Quoted in Fouts, Jefferson the Inventor, 4 J. Pat. Off. Soc. 316, 325 (1922).

292 Stat. 318 (1793). 
was rejected by early decisions of the Supreme Court. ${ }^{30}$ This Court, like those of England, insisted on a judicial review of the administrative judgment over patents; $;^{31}$ and for some considerable time, it applied at least somewhat stricter rules on inventiveness.

Those times came to an end with Winans $v$. Denmead in $1853,{ }^{32}$ a case involving a coal car with a hopper bottom. The decision passed on several basic questions of patent law. For present purposes it must be noted that the majority decision (announced by Justice Curtis subject to a dissent of Justices Taney, Catron, Daniel and Campbell) declared:

In this as in most patent cases it is necessary to inquire (1) what is the structure or device...; (2) what mode of operation is introduced ...; (3) what result is attained. (Emphasis added.) $)^{33}$

This analysis has been controlling from then on, whether new results were found present ${ }^{34}$ or absent. ${ }^{35}$ The present American patent system, substantially resembling the English one, was practically completed by this rule.

It is impossible in this essay to explore all the reported opinions but it can be noted that lower federal courts as well as text book writers seemed ready, throughout the formative period, to invalidate patents for lack of inventiveness. ${ }^{36}$

However, specific reference must be made to one Circuit Court case decided in 1825: Justice Story's decision in Earle v. Saryer. ${ }^{37}$ The patent enforced in that case covered a "shingle machine," old by itself. While a reciprocating saw was usual in such a machine, the new machine used a circular saw, which also was old by itself. An infringement action was brought, and the defendant pleaded invalidity of the patent due to lack of

${ }^{30} \mathrm{~A}$ vague reference to the problem occurred in Prouty v. Ruggles, 16 Pet. (U.S.) 336 (1842). More definite was Hotchkiss v. Greenwood, 11 How. (U.S.) 248, 266 (1850): "This . . . produced a new and peculiar effect . . . but . . . unless more ingenuity . . . were required ... there was an absence of . . . invention." In LeRoy v. Tatham, 14 How. (U.S.) 156, 174 (1852), the court below had said: "If this combination is new and produces a new and useful result it is the proper subject of a patent." The Supreme Court reversed on this specific ground. Three Justices dissented.

${ }^{31}$ Reckendorfer v. Faber, 92 U.S. 347 (1875), and earlier cases cited therein; Mahn v. Harwood, 112 U.S. 354 (1884).

3215 How. (U.S.) 329 (1853).

${ }^{33}$ Ibid., at 337 .

${ }^{34}$ As in Seymour v. Osborne, 11 Wall. (U.S.) 516 (1870); Mowry v. Whitney, 14 Wall. (U.S.) 620 (1871).

${ }^{35}$ As in Hicks v. Kelsey, 18 Wall. (U.S.) 6 to (1873); Hailes v. Van Wormer, 20 Wall. (U.S.) 353 (1873).

${ }^{36}$ See Collier, Patents 75 (1803); Phillips, Patents 125-35 (1837); Godson, Patents and Copyrights 54-56 (1840).

${ }^{37} 4$ Mason (Mass.) 1 (1827). 
invention. He argued that only that can be invention which "would not occur to all persons skilled in the art." He also referred to the new result principle and claimed absence of a new result.

These arguments are now accepted as controlling. Justice Story rejected them. He made two points: First, that the degree of the patentee's mental or experimental effort is irrelevant; and second, that aside from matters lacking in novelty and utility only that "may" be unpatentable which is "absolutely frivolous and foolish."

The first point was in keeping with English practice ${ }^{88}$ and has been plausible enough to be cited in hundreds of cases after Earle v. Sarwyer. However it was practically only in Earle v. Sareyer that this point was construed as an argument against comparison of the alleged invention with the routine contributions of "persons skilled in the art." Both previously and subsequently, patent monopolies for mere routine developments were considered as impediments rather than incentives for the progress of the useful arts.

The second point made by Justice Story established, temporarily, a judicial patentability standard of unprecedented lowness. The standard of Lord Coke had been strict; that of Lord Mansfield, milder; that of Thomas Jefferson, intermediate; but no one had ever said that invention starts directly above the level of the "absolutely frivolous and foolish." It is hard to see, in view of other cases decided by Justice Story, ${ }^{39}$ how the brilliant jurist could adopt such a rule.

To some extent this may be explained by the fact that the decision was written under the act of 1793 , which recited one and only one of the then known negative rules on invention. While the reported opinion does not say so, its author may have felt that postulating other negative rules would amount to improper judicial legislation.

In 1836 all reference to such specific standards was removed from the statute. ${ }^{40}$ From then on the old and new negative rules were developed vigorously, ${ }^{41}$ along with the positive rule the growth of which we have

${ }^{38}$ Liardet v. Johnson (1778), 1 Web. Pat. Cas. 53 (1844).

39 E.g., Whittemore v. Cutter, 1 Gall. (Mass.) 478 (1813). Of that case Justice Story said in Earle v. Sawyer: "To that decision ... I still adhere, although, I confess with subdued confdence, since $I$ have reason to believe, that it has not met the entire concurrence of other and abler judicial minds." 4 Mason (Mass.) 1, 12 (1827). In express terms this remark related only to a question of measure of damages; however, it seems interesting in general. Justice Story returned to the sounder inventiveness principles of his earlier decision in Howe v. Abbott, 2 Story (Mass.) 190 (1842), and Bean v. Smallwood, 2 Story (Mass.) 408 (1843).

10 Stat. 117 (1836).

"Prouty v. Ruggles and Hotchkiss v. Greenwood, op. cit. supra note 30; Phillips v. Page, 24 How. (U.S.) 164 (1860); Stimpson v. Woodman, 10 Wall. (U.S.) 117 (1869); Brown v. Piper, 91 U.S. 37 (1875). 
traced. The statute of 1836 also reestablished administrative pre-examination of patents, abolishing a system of exclusive judicial action which had been adopted in 1793. The U.S. Patent Office was now established, staffed for patent examination and empowered to pass on all requirements for patents, including adequacy of specification, novelty, inventiveness, and even the question whether the invention, if any, is "deemed sufficiently useful and important" to merit a patent monopoly. This was the second great contribution of America in the field of patents, if Jefferson's rules were the first. Again it was a contribution on the administrative side; not a new achievement of the judicial mind.

\section{STANDARDS OF INVENTTON UNDER THE SYSTEM OF 1836}

The Patent Office made only conservative use of its statutory discretion. It continued to use and very gradually to develop the rules and standards of Jefferson. The examining divisions of the Office, which had to be established in growing numbers - today there are seventy of themwere not subjected to any changing, administrative paraphrases of the standards to be applied. They were left free to apply the pertinent case law, including of course the conflicts and contradictions therein.

The courts which contributed to this case law by their judicial review of patents, announced standards which varied both in place and time. They were not always satisfied with the mere development of existing standards. The conflicts and contradictions in the law of "invention" came more from court review than from the primary, administrative practice.

It does not follow that the Patent Office was generally right, nor does it follow that it was generally wrong. It only follows that the Office was conservative, as compared with the courts. The degree and the type of this conservatism will now be analyzed. ${ }^{42}$

As the territory and population of the United States grew, the number of patents also grew. In the beginning it grew more than proportionally. During the period of mass immigration the per capita number of patents

42 The first tabulation which follows is based on Hamilton, Patents and Free Enterprise, Exhibit 181 (TNEC Monograph, 1941). The second tabulation is based on Hamilton, ibid., at Exhibit 179, and Boyle, Patents and Property, 19 J. Pat. Off. Soc. 459 (1937). The third is based on Federico, Preliminary Survey of Adjudicated Patents, 1929-1934, 18 J. Pat. Off. Soc. 685 (1936), and Evans, Disposition of Patent Cases by the Courts, 24 J. Pat. Off. Soc. 19 (1942). Also see Federico, Patents in Circuit Courts of Appeals, 1925 to 1936, $20 \mathrm{~J}$. Pat. Off. Soc. 72 (1938); Brown, Developments in the Patent Law as Affected by Adjudications, $22 \mathrm{~J}$. Pat. Off. Soc. 587 (1940); GilFillan, Inventiveness by Nation and State, 12 J. Pat. Off. Soc. 259 (1930). 
rose sharply, although it never reached such high levels as it has in some of the older countries. After 1880 the American per capita figure remained at the fairly high level once established. Approximate average yearly numbers of patents issued in this country, per million persons, were as follows:
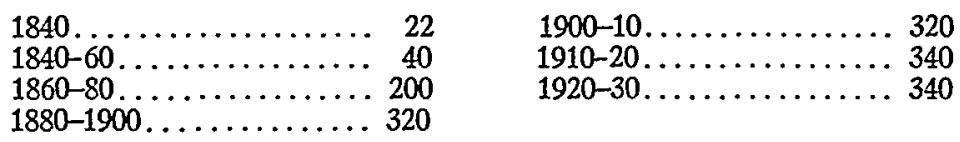

The only significant change, after 1880 , was that an increasing number of patents was taken out by employers who thereby acquired patent holdings. of greater consequence. For instance the companies taking out more than ten patents per year accounted for two per cent of the total yearly issue in 1900 , ten per cent in 1935 and nineteen per cent in 1936. The resulting problems of concentration of national wealth are independent from those of the inventive standards; however the enforcement of adequate standards is a matter of special concern to small business.

To some extent the rapid increase of patents, between 1840 and 1880 , was encouraged by a relatively lenient treatment of patent applications in the Patent Office. This appears from the following figures, showing average percentages of patent rejections on the basis of total yearly numbers of patent applications:

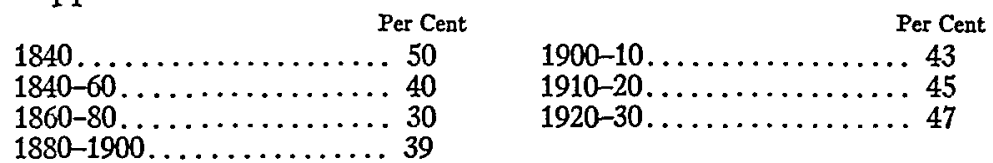

It will be seen that the downward trend of these percentages during the first forty years was slight, as compared with the simultaneous rise in the per capita number of patents issued. Plainly, there was an increase in national inventiveness and enterprise. The favor shown to patent applicants was a result of this popular trend, as well as a further stimulant.

The reaction of the courts is known starting about 1880 . We mainly have the Supreme Court percentages of holdings of "invalid" on the basis of total patent infringement cases:

\begin{tabular}{|c|c|}
\hline Per Cent & Per Cent \\
\hline 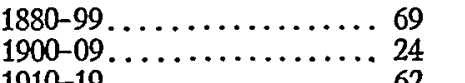 & $\begin{array}{l}1920-29 \ldots \ldots \ldots \ldots \ldots \ldots .8{ }^{50} \\
1930-40 \ldots \ldots \ldots \ldots \ldots\end{array}$ \\
\hline
\end{tabular}

That these figures fluctuated widely is not too surprising, in view of the small number of cases reaching the Court yearly. More surprising is the 
fact that equal or greater fluctuation is shown by the average validity standards of lower federal courts, so far as known. This may be an effect of the appointment system in the courts, as compared with the career system in the Patent Office. This should be considered in connection with proposals which come up from time to time and which would hand the judicial review of patents to a single court, on an appointed basis.

It is also interesting to know what portion of the patent cases involved an issue about invention, as distinguished from issues of lacking novelty, accuracy, infringement, etc. A sample is furnished by the period 1940 1949. The Supreme Court decided approximately forty-six patent cases, including eleven cases involving issues of invention, with nine cases denied invention, while two cases found invention.

II

The more important cases on invention must now be analyzed individually. The two separate criteria mentioned from Earle v. Sawyer ${ }^{43}$ will serve as points of reference:

Point 1 was that invention depends on a sufficient objective contribution to the industry, not on any sufficient personal efforts as brilliant thoughts or patent searches. This clearcut and plausible doctrine was rarely followed and frequently rejected by the Supreme Court. ${ }^{44}$

It was also confused. Some confusion about it was probably due to the old term "ingenious" as well as the new term "unobvious." These terms have a personal tinge, even when the question is posed whether the ingenuity or unobviousness is reflected by the new structure or process. Confusion of this issue seems hard to avoid whether the Court investigates the patentee's alleged ingenuity and unobvious performance, or the powers of the imaginary skilled mechanic.

Actual self-contradiction occurred in a recent Supreme Court case, involving a new, special printing ink.$^{45}$ The Court gave lip service to the doctrine that the patent system is "not concerned with the quality of the inventor's mind but with the quality of his product." However it proceeded directly and abruptly to invalidate the patent on the sole basis that the new ink "was not the product of long and difficult experimentation"

${ }^{48}$ See text at note 37 supra.

"It was followed in McClain v. Ortmayer, 141 U.S. 419 (1891). It was rejected, for instance, in Hollister v. Benedict \& Burnham Mfg. Co., 113 U.S. 59 (1885); also see note 45 infra.

$₫$ Sinclair Co. v. Interchemical Corp., 325 U.S. 327 (1944). Justices Douglas and Black concurred only in the result. Also see the discussion of this case by Duft, Supreme Court Announces Rule for Measuring Inventions and Then Fails to Apply It, 27 J. Pat. Off. Soc. 779 (1945). 
but that the patentee had produced it with apparent ease, by selecting a certain catalog and selecting certain constituents of the ink therefrom.

It seems, then, that the Supreme Court has generally, but not very clearly, insisted on weighing personal factors along with objective industrial factors.

Point 2 of Justice Story's holding in Earle v. Sawyer had established a standard according to which everything was entitled to a patent monopoly which was new and useful and surpassed, no matter how slightly, the level of the "absolutely frivolous and foolish." This was clearly overruled by the Supreme Court in Hotchkiss v. Greenwood. ${ }^{46}$ The patentee in this case had fastened a doorknob of clay or porcelain, a well-known material, to a known type of doorknob shank, by a known metal bond, applied in a molten state. Previously, wooden or metal knobs had been used on similar shanks, sometimes with similar bonds. The patentee claimed that the combination of the shank, knob and bond produced a new result in that the metal bond not only held the knob-as before-but also strengthened it. The Court invalidated the patent. It continued, in effect, Jefferson's second rule. It refused to give weight to the new result alleged, while apparently admitting it. Most important, the Court used language similar to that of the unsuccessful defendant in Earle v. Sawyer, establishing the "ordinary mechanic" as a standard of reference. Even mechanics, the majority said, have "ingenuity and skill." A high "degree" of these gifts is required for a showing of invention.

The Court's attitude in the new result question, as mentioned, was reversed three years later. After the Civil War the Court became still more lenient with patents. This relatively lenient trend started with the admission of new positive rules or standards, in Smith v. Goodyear Dental Vulcanite $\mathrm{Co}^{47}$ The existence of unsuccessful prior attempts, and of commercial success after the patent, was allowed to resolve a doubt whether there was a new result and whether there was invention. In this case, plates for artificial teeth were involved. The prior art had used combinations of guttapercha plates and porcelain or similar teeth, among other things. The patentee used the same porcelain teeth, set in vulcanized rubber, a material well known as such. The Court attempted to distinguish the new case from Hotchkiss v. Greenreod by declaring that the new plate was a "one piece" article; a distinction of the flimsiest kind. The Court added that a suitable plate material

had been an object long and earnestly sought. ... [I]t has wrought a revolution in dental practice. ... [T]housands of operators use it. ... We do not say the ... general

4s 11 How. (J.S.) 248 (1850).

1793 U.S. 486 (1876). 
use . . . establishes in all cases . . . a patentable invention. It may, however, always be considered; and when the other facts leave the question in doubt, it is sufficient to turn the scale. 48

As a result of this case we now have three positive standards of invention, or positive rules of evidence for the presence of this evasive quality: new results, long unsuccessful attempts before the patent, and commercial success after the patent.

The further development of the Supreme Court law consisted largely in applications and occasional elaborations of such rules; not without reversals of opinion in questions involving details. With regard to the test provided by commercial success, the Court was generally cautious; it insisted that the success must be traceable to the new structure or process, and that, even when so traceable, it is relevant only to resolve an existing, legitimate doubt, not to create and resolve a doubt. ${ }^{49}$ With regard to the prior lag or unsuccessful attempt principle, the Court has become increasingly favorable to patentees in relatively recent decades. ${ }^{50}$

The basic positive rule was and remained that looking to the presence or absence of new, beneficial results. Definitions of this all-important concept were rarely undertaken, but there were suggestions of variable trend. In 1874 and 1875 it was announced that a claimed new result, consisting only in a changed "degree" of a known result, is insufficient to sustain a patent, and that there is required something like a "different force or effect"; but these principles were silently dropped in the pivotal case of Loom Co. v. Higgins..$^{51}$ Nevertheless, a difference was made and should be made between new results, which are unqualifiedly pertinent to the question of inventiveness, and commercial success, which is pertinent only to resolve an existing doubt as to this question.

The Loom Co. case was of importance for more than the new result rule. It lowered the standard of patentable invention in principle. In and after this case, no reference was made to "ingenuity" any more; at least not for a long time. "Unobviousness" became sufficient. The Court said:

We cannot yield our assent to the argument that the combination ... was so obvious as to merit no title to invention. ${ }^{52}$

18 Tbid., at 495-96.

49 Textile v. Hirsch, 302 U.S. 490 (1937); Toledo Pressed Steel Co. v. Standard Parts, Inc., 307 U.S. 350 (1939).

${ }^{50}$ Richmond v. United States, 275 U.S. 331 (1927); DeForest v. General Elec. Co. 283 U.S. 664 (1930).

51105 U.S. 580 (1881). The two earlier cases were Smith v. Nichols, 21 Wall. (U.S.) 112 (1874), and Reckendorfer v. Faber, 92 U.S. 347 (1875).

22 Tbid., at 591 . 
By now, the statutory concept of invention had been defined as something better than foolish, and as something highly ingenious. The Court now settled on the middle ground of something better than obvious. Neither of these terms is self-executing or self-explanatory; the detailed rules of invention were required, and used, to answer most of the actual questions.

The "negative rules" were enforced and amplified as well as the "positive rules." As a result it is now usual to say that evidence against invention lies not only in the three situations listed by Jefferson but also in: a mere rearrangement of elements, a mere omission of elements, mere duplication or multiplication of elements, and mere superior workmanship.

Still further a rule was developed that a new arrangement of elements old or new, wherein the different elements cooperate with one another, is an inventive "combination," while one wherein they do not so cooperate is a noninventive "aggregation." This is sometimes considered as one of the negative rules, but can also be considered as a rule occupying middle ground between the negative and positive standards. If the elements are old, the Supreme Court insists on a new kind of cooperation for which a new result is generally admitted in evidence.

These several rules are stated and basically approved in all current books on patent law. Their exact operation and interrelation is the subject matter of a large body of case law, in the Patent Office and in the courts. The rules were rather uniformly applied by all tribunals until 1941 .

By virtue of these detailed rules, it was relatively unimportant whether the general test was based on "high ingenuity" or only on something "unobvious." The detailed rules stabilized the law. Changes in the general trend, of course, took place from time to time, and were judicially noted; $;^{54}$ but due to the detailed rules their effect was relatively minor.

The last change in general trend, however, became major. This started under Chief Justice Hughes, but the full significance of this last change became apparent only under Chief Justice Stone. It amounted to the complete, although silent, abandonment of the entire set of positive and negative rules by the Supreme Court, in favor of new, generalized paraphrases of "invention."

This became clear in the so-called Flash of Genius case, Automatic Devices v. Cuno Engineering Corp. ${ }^{55}$ although the case is usually discussed in

${ }^{53}$ Hailes v. Van Wormer, 20 Wall. (U.S.) 353 (1873); Reckendorfer v. Faber, 92 U.S. 347 (1875), and many subsequent Supreme Court cases up to Lincoln Co. v. Stewart-Warner Corp., 303 U.S. 545 (1937). 1894).

6 E.g., Gamewell Fire-Alarm Tel. Co. v. Municipal Signal Co., 61 Fed. 948 (C.A. 1st,

55 314 U.S. 84 (1941). Mr. D. W. Cooper represented the patentee. 
a narrower sense. The issue in this case involved a new and useful cigarette lighter, adapted for mounting on an automobile dashboard by a cordless construction, known as such. The device also used a thermostatic spring latch release, known as such. It was found sufficiently useful and important for a patent by the Commissioner of Patents. The patent was held valid by the Second Circuit Court of Appeals but invalid by the Seventh. One of the essential prior art references against the patent was available to the courts but had not been available in the Patent Office proceedings.

The Seventh Circuit, which certainly was not hostile to patents, found that both the cordless construction and the automatic release were old in the art and that the patent "made no use of any new principle" in putting them together.$^{56}$ In other words, the case was under the first negative rule of Jefferson, and was not rescued by the positive rules.

This was affirmed, ${ }^{57}$ but for much more generalized reasons. Justice Douglas, writing the opinion of the Supreme Court, conceded that the "functions" of the "combination" were new. This they were certainly not, according to the decree affirmed and according to the Supreme Court's earlier rules. He then announced that the ingenuity standard of Hotchkiss ข. Greenwood requires "strict application." His application was rhetoric rather than strict. He was no longer satisfied with a "high degree" of genius but required a "flash" of it, to be revealed by the device.

Obviously the Court here indulged in the old vagueness about the problem forming Point 1 of Earle v. Sawyer; and for the first time, it allowed this vagueness to affect the operation of the positive and negative rules of invention.

Earlier Supreme Court cases, even earlier Supreme Court dissents, furnished no apparent reason for this sudden setting aside of an integrated set of rules. Nor is it possible that the rules were simply unknown to the Court. What, then, was the reason for the change in approach?

\section{III}

Abroad there had been opposition against some of the detailed rules of invention. The development of these rules, and the periodic movements against them, were international in scope. ${ }^{58}$ In this country, the opposition against the conventional rules was carried, openly and energetically, by a small number of men headed by Judge Learned Hand.

This able jurist was distinctly on the side of liberality to patentees. He

${ }^{38}$ Automatic Devices Corp. v. Sinko Tool \& Mfg. Co., 112 E. 2d 335 (C.A. 7th, 1940).

${ }^{57} 314$ U.S. 94 (1941).

See, e.g., Glascock and Stringham, Patent Soliciting and Examining 345-50 (1934). 
strongly attacked such rules as that against aggregations. ${ }^{59}$ While he knew that reliance on commercial success is "extremely apt to lead one wholly astray," 60 he was led astray by it himself. Under his hands, the new result rule became indistinguishable from a commercial success rule, without investigation of factors raising a reasonable doubt, and without investigation whether the success was traceable to the features claimed in the patent.

Shortly before retiring from the bench, Judge Hand was so deeply imbued with his own lenient ideas about patent standards that he treated the conventional rules, both positive and negative, as no longer extant. A typical case was that of Jungersen v. Baden. ${ }^{61}$ The patent described and claimed a form of producing custom jewelry by a sequence of mold and pattern forming operations for primary and secondary molds and fillings of rubber, plaster, wax and metal. Centrifugal filling was used in a known manner at each step. The mold and pattern materials were well known. The exact sequence of operations was new. According to the settled law of the last eighty years it was at least most probable, if not certain, that the patent was invalid as covering a mere aggregation of steps known by themselves, producing known results, and not interrelated in any new manner. It was hard to see where any doubt about invalidity should arise. If there was a doubt, it was because there was also commercial success; however it was not to be seen at all why the success was traceable to the new sequence of the well-known steps. True, the industry had not used that sequence, but it had known all the steps. Assuredly the patentee had not shown any new principles; he had only been enterprising in using known things, when the rest of the industry had left those things unused. Judge Hand declared that the patent showed "every hall-mark" of an invention. Indeed, it had every ball-mark recognized by him; be disregarded the aggregation rule and took the so-called revolutionizing of the industry, effected by Jungersen, as a new result, not as commercial success.

${ }^{59}$ E.g., Scott \& Williams v. Aristo Hosiery Co., 300 Fed. 622 (S.D.N.Y., 1924). Dubilier Condenser Corp. v. N.Y. Coil Co., 20 F. 2d 723 (C.A. 2d, 1927); Bragg-Kliesrath Corp. v. Farrell, 36 F. 2d 845 (C.A. 2d, 1929); Sachs v. Fartford Elec. Supply Co., 47 F. 2d 743 (C.A. 2d, 1931); B. G. Corp. v. Kidde \& Co., 79 F. 2 d 20 (C.A. 2d, 1935). A predecessor of Judge Hand, in this connection, was Judge Coxe. See, e.g., Gould Coupler Co. v. Pratt, 70 Fed. 622, 624 (N.D.N.Y., 1895): "Invention should be determined more by an ascertainment of what the inventor has actually accomplished than by a technical analysis of the means by which the result is attained." In the Patent Office, somewhat similar views have been voiced by Dawson, Some Notes on the Doctrine of Aggregation, 26 J. Pat. Off. Soc. 838 (1944). For Hand's position generally, see Philbin, Judge Learned Hand and the Law of Patents and Copyrights, 60 Harv. L. Rev. 394 (1947).

${ }^{60}$ Foxboro Co. v. Taylor Instrument Co., 157 F. 2d 226, 233 (C.A. 2d, 1946).

61166 F. 2d 807 (C.A. 2d, 1948), Judge Learned Hand dissenting. 
Like earlier decisions of Judge Hand, the Jungersen opinion was rejected by a majority of the Supreme Court. ${ }^{62}$ However, it was not rejected on the basis of the settled law. It seems a forceful judge leaves an imprint of his thought even on the reversing tribunal. Both majority and dissenters on the Supreme Court are clearly affected by Judge Fland's viewpoints. Since the majority disagreed with his results, and disregarded the established methods of the law, it appears that they were confused.

The confusion, as mentioned, had already appeared on the surface in the Flash of Genius case. ${ }^{63}$ It became more obvious in the Supreme Court's action on the Jungersen case. Justice Frankfurter's dissent, in favor of validity, simply adopts the view of Judge Hand. Justice Jackson's dissent in this case goes so far as to say expressly that the Court should be guided by the "revolutionizing of the industry," rather than by the existence of ancient references of prior art. This view ${ }^{64}$ leads to patents for advertisers; an industry can be revolutionized by skillful advertisement as well as by the most ingenious invention. However, Congress has no power to secure exclusive rights to advertisers; and when courts, by way of judicial legislation, attempt to create such rights, their action is unconstitutional. The majority speaks of Jungersen's "combination" as a matter of course, completely disregarding the pertinent law long announced by the Court, and not even discussing the question of aggregation. The settled law against patents for mere aggregations furnished plausible and valid grounds for the disapproval of Judge Hand's opinion, while the grounds stated by the majority come down to arbitrary disagreement without plausible or ascertainable principle. The majority was confused by Judge Learned Fand, while the dissenters followed him advisedly on his path which according to the conventional rules is wrong.

\section{IV}

A feeling of embarrassment and futility has arisen due to this strange confusion. This feeling has led to frequent expressions by lawyers, denying the right and responsibility of judicial review over technical matters. ${ }^{65}$ However it should be noted that cases on "simple" store counters, printing

¿2 Jungersen v. Ostby \& Barton Co., 335 U.S. 560 (1949).

${ }^{63}$ Op. cit. supra note 55.

64 Previousiy rejected by Justices Frankfurter and Jackson; see their concurring and dissenting opinions in the Flash of Genius Case, op. cit. supra note 55, and in Goodyear Co. v. Ray-O-Vac. Co., 321 U.S. 275 (1944).

${ }^{65}$ See the opinion of Fand, Learned J., in Parke-Davies \& Co. v. Mulford Co., 189 Fed. 95, (S.D.N.Y., 1911); the dissent of Jackson, in the Jungersen case, op. cit. supra note 62; Medina, A New Judge Tries His First Patent Case, 34 Cornell L.Q. 220 (1948); and Borkin, The Patent Infringement Suit-Ordeal by Trial, 17 Univ. Chi. L. Rev. 634 (1949). 
inks, cigar lighters and flashlight batteries give the courts as much trouble, if not more, as do the occasional cases involving electronic circuits or advanced chemistry. Therefore the problem seems to involve the law of patents rather than science and technology.

A much-quoted statement by Justice Frankfurter is to the point. It says, provokingly: "The basic assumption of our patent law may be false." ${ }^{166}$ This was occasioned by a decision of the Supreme Court majority, invalidating a secondary but important radio patent of Marconi. ${ }^{67}$ The holding of the majority involved only an issue of lacking "novelty," in view of a certain prior art specification; but there were dicta, of debatable merit indeed, which indicated a readiness to strike down even one of the pioneering contributions to modern civilization for an assumed lack of "inventiveness."

If "the basic assumption of our patent law" be that of Thomas Jefferson, and of the famous patent cases of the nineteenth century, there is no cause whatsoever for the pessimism so provokingly suggested by Justice Frankfurter. There is cause for this pessimism only when disregarding, with Judge Hand and with Justice Frankfurter himself, those basic assumptions and rules which are historically settled. Justice Frankfurter's dissent does not recognize the clear justification for the majority holding in the Marconi case and does not single out the questionable dicta. It does not analyze the problem of invention, either on the basis of pasitive or negative rules. It speaks of the nontechnical training of judges, the great discoveries of science, the social merits of radio, and-last but not leastthe fact that Marconi had commercial success. All these, however, are mere generalities. The dissent as well as the majority opinion discloses disregard for the settled patent law. It discusses a confused issue in a confused manner, if the settled law be taken as binding.

The next development was that "basic assumptions" of a very novel kind were proposed. One such proposal was that of Judge Jerome Frank and C. W. Dawson that patents of inventors could be supplemented or replaced by patents of investors in research. ${ }^{68}$ This is rather reminiscent of the patents to the financiers of Queen Elizabeth and King James. While not entirely devoid of constructive functions, those patents had to be stopped by the Statute of Monopolies. ${ }^{69}$ It can hardly be expected that the new investors' patents would be held legal under the Constitution.

*8 Marconi Wireless Co. v. United States, 320 U.S. 1, 63 (1943). $\quad 67$ Ibid.

os See the concurring opinion in Picard v. United Aircraft Corp., 128 F. 2d 632, 638 (C.A. 2d, 1942); Dawson, Research as a Criterion of Invention, 29 J. Pat. Off. Soc. 567 (1947).

s9 21 Jac. 1, c. 3 (1623). 
Differently directed but equally devious was the further development of the Supreme Court majority standpoint. There was no analytic, historical or systematic thinking in this development. The standards gradually became so vague that they even started spreading confusion in fields other than "invention." Recent cases about so-called "gadgets" carried confusion into the field of subject matter for patents. The first of these cases was Great A. \& P. Tea Co. v. Supermarket Corp.$^{70}$

Until then it had been clear under the patent statute ${ }^{71}$ that mechanical patents are available for four types of subject matter: processes, machines, compositions of matter and last not least the so-called manufactures, also known as implements or gadgets. In the $A$. $\& P$. case, Justice Douglas wrote a concurring opinion, asserting that "the Constitution never sanctioned the patenting of gadgets. Patents serve a higher end-the advancement of science."72 This was about as clearly wrong as a judicial opinion on an intricate matter can possibly be. It was based on a complete disregard for the constitutional promotion of the useful arts. However, at least it was clear.

Less clear but equally wrong was the majority opinion. It stated that a patent covering a "combination" of old elements is subject to an "improbability of finding invention." When speaking of "combination," it again disregarded former Supreme Court concepts about aggregation. It seemed to create a new and questionable class of old-element assemblies. Incidentally the scope of the majority opinion is broader than that of Justice Douglas' concurring view; it is not limited to gadgets. Or is it? It speaks of combinations in "mechanics." By way of dicta it suggests that the new "improbability of invention" does not apply to "chemistry or electronics." The patent profession has protested against these innovations in the law. ${ }^{73}$

There were some earlier cases of related nature. The Court had questioned whether methods of doing business can qualify as patentable matter, or as invention. ${ }^{74}$ It had similarly questioned a product largely composed of living bacteria. ${ }^{75}$

70340 U.S. 147 (1950).

718 Stat. 954 (1870).

72 Great A. \& P. Tea Co. v. Supermarket Corp., 340 U.S. 147, 155 (1950).

${ }^{73}$ See Siggers, Comments on Great Atlantic \& Pacific Tea Co. v. Supermarket Equipment Corp., 33 J. Pat. Off. Soc. 83 (1951); Holbrook, Science v. Gadgets, ibid., 87; Broder, Gadget Patents, ibid., 102; Miller, Comment on the Intentions of the Framers of the Constitution, ibid., 148; Michel, The Standard of Invention and the U.S. Supreme Court., ibid., 297; Oberlin, "Science" versus "Useful Arts," ibid., 399; Fellner, Austerity Standards and War Effort, ibid., 475; Greenberg, "Gadget" Patents, ibid., 569.

74 Munson v. New York City, 124 U.S. 601 (1888).

${ }^{\top}$ Funk Bros. Seed Co. v. Kalo Innoculant Co., 333 U.S. 127 (1948). 
However the $A$. \& $P$. case does not refer to those earlier cases. It seems unconcerned about consistency and precedent-although the case is now beginning to become a precedent itself. ${ }^{76}$ The Court seems grimly determined to enforce higher patent standards, disregarding all "fine points" in this effort.

This attitude seems intemperate and unlikely to succeed. The new formulas are partly meaningless, partly in unresolved conflict with earlier, unrevoked Court principles. Thus they provoke the seeming insubordination of some lower courts, and the practice of others, who cite the new cases but actually disregard them.

The Patent Office itself has been much more consistent with regard to standards of invention; not only statistically but likewise in the rules and formulations announced. It has been free from the Flash of Genius rule, but also from the fallacies of commercial success.

The Office has used, and uses, the nonobviousness standard of the Loom Case: The Supreme Court standard of 1882.

The Court of Customs and Patent Appeals, which practically is the tribunal of final resort for Patent Office contests, has endorsed and actually enforced this standard. It has demonstrated its determination and apparent power to preserve this standard in the Patent Office, regardless of any new Supreme Court paraphrases of the word "invention." This was the expressed purpose and significance of its decision in the patent appeal case, In re Shortell. ${ }^{77}$

Shortell's application disclosed and claimed a new hacksaw blade with teeth on both edges, the teeth of the two rows having different "set." Double rows of saw teeth were known as such. Different set of different teeth was known as such, in single rows. In Shortell's saw blade, the difference in "set" produced a new and beneficial result: an increase in total cutting capacity over comparable single row or double row blades.

The Examiner rejected Shortell's application as failing to reveal the flash of genius. The Board of Appeals affirmed. The court in this case did what it does rarely-it reversed both lower tribunals. It made the point very olear that in its opinion the flash of genius standard is improper and

76 Crest Specialty v. Trager, 341 U.S. 912 (1951).

77142 F. 2 d 292 (Cust. \& Pat. App., 1944). For background, see Richard, Ex Parte Appeals to the Board of Appeals in the United States Patent Office, 25 J. Pat. Off. Soc. 375 (1943), and Richard, Standards of Invention in the Patent Office As Affected by Recent Decisions, $27 \mathrm{~J}$. Pat. Off. Soc. 24 (1945). This decision was criticized by Hand, J. in Foxboro Co. v. Taylor Instrument Co., 157 F. 2d 226 (C.A. 2d, 1946). 
will not be tolerated in the Patent Office. The court's definition of the proper standard-incidentally not based on any significant citations of authority-is this:

If a process or thing ... would not be obvious to one skilled in the art, invention should be presumed.. ${ }^{28}$

The court seemed to feel that this standard differs from the genius or flash of genius standard. The Supreme Court agrees that it differs, and feels that it is too low. Of course the Supreme Court of today, in so holding, disregards the Supreme Court holdings of 1882, etc.; and the other court, in revolting from the new Supreme Court rule, disregards the Supreme Court holdings of the time before as well as after the years about 1882.

So far, the victory in this unpleasant contest has been with the lower court, whose opinion has controlled ten thousands of Patent Office decisions each year. For the great majority of the resulting patents, the Supreme Court standard is purely academic. This does not mean that the patents are not enforced. Many of them are enforced by out-of-court settlements; and in the Seventh Circuit they can be enforced at least up to the Circuit Court of Appeals.

It is frequently assumed, but by no means true, that the entire Patent Office standard of invention is lower than the Supreme Court standard. This is true only of generalized terms like "ingenuity" and "unobviousness"; and fortunately, it is but rarely that cases are decided, in the Patent Office, by reference to such generalized terms. The great majority of the patent applications are scrutinized from much more specific viewpoints; and these are, often, more exacting than the parallel standards announced or implicitly applied by the present Supreme Court majority. They are considerably higher than are the standards of the dissenting Court minority.

Particularly the rule against aggregations is being enforced by the Patent Office; and very properly so. Fine ramifications of this rule have been developed. In some details the Office may even be too strict; in others not strict enough. Likewise, errors may occur in the application of the finer details to individual cases. The important point, however, is that the conservatism of the Office means greater, not lesser strictness with patent applications, in this important phase of the law.

Even in the practical application of the ultimate test of unobviousness, the Patent Office has fairly strict rules. It is ready to assume that a fairly wide range of new developments can be "expected" on the ground of the

${ }^{78}$ In re Shortell, ibid., at 296. 
prior art, although the various divisions differ in this respect. ${ }^{79}$ Likewise many divisions are ready to apply the rule that "the mere necessity of experimentation does not indicate invention." ${ }^{80}$ Finally the Office insists, very properly, on its right to cite two or more prior art references (earlier patents, publications, etc.) in combination with one another, to support the rejection of a claim. ${ }^{81}$ Indiscriminate combinations of prior art references, so-called "mosaic" or "shotgun" citations, are usually reversed upon appeal to the Board of Appeals within the Patent Office, or to the Court of Customs and Patent Appeals; but combinations within the command of the skilled artisan are given full effect, at least in the great majority of the cases.

In several of these detail questions decisive for invention and patentability, the Patent Office is much stricter with patent applications than are the Courts, including the Supreme Court. This fact is often forgotten by the courts and by others, but the discussion is unrealistic if it is not remembered.

The aggregation rule is perhaps the most outstanding example now.

${ }^{79}$ In re Goessling, 108 F. 2d 266 (Cust. \& Pat. App., 1940); In re Boyce, 144 F. 2d 896 (Cust. \& Pat. App., 1944); In re Swain, 156 F. 2d 239 (Cust. \& Pat. App., 1946). About the development of predictability rules for chemistry in the Patent Office, see Bull, Provision in the Law of Chemical Patents, 25 J. Pat. Off. Soc. 473, 535 (1943).

${ }^{80}$ In re Berger, 143 F. 2 d 971 (Cust. \& Pat. App., 1944); In re Staeger, 183 F. 2 d 99 (Cust. \& Pat. App., 1950). The Court of Appeals for the District of Columbia, which has a jurisdiction somewhat parallel with that of the Court of Customs and Patent Appeals, has decided similarly in Minnesota Mining \& Mfg. Co. v. Coe, 99 F. 2d 986 (App. D.C., 1938), and SherwinWilliams Co. v. Marzall, 190 F. 2d 606 (App. D.C., 1951). It stated the same doctrine in Potts v. Coe, 140 F. 2d 470 (App. D.C., 1944); here it added that the doctrine applies with special strictness in cases originating in "the great corporate laboratories." This discrimination against investors was just as unjustified as Judge Frank's proposal of special favor to investors would be. Picard v. United States, 142 F. 2d 292 (Cust. \& Pat. App., 1914). The decision in Potts v. Coe, supra, was written by Judge Thurman Arnold.

81 Ex parte Fine, [1927] Comm'r. Dec. 84; In re Wenzel, 88 F. 2d 501 (Cust. \& Pat. App., 1937); In re Milne, 140 F. 2d 1003 (Cust. \& Pat. App., 1951); In re Laurent, 186 F. 2d 741 (Cust. \& Pat. App., 1951); In re Lindberg, 93 U.S.P.Q. 23 (1951). Similarly some recent decisions in infringement cases: Foxboro Co. v. Taylor Instrument Co. 157 F. 2d 226 (C.A. 2d, 1946); Himmel v. Serrick, 122 F. 2d 740 (C.A. 7th, 1941); Richmond Screw Anchor Co. v. Umbach, 173 F. 2d 524 (C.A. 7th, 1949). Contra: occasional Patent Office decisions, see, e.g., Glascock and Stringham, Patent Law 227-29 (1943); also various infringement cases, e.g., Independent Coal Tar Co. v. Cressy, 260 Fed. 463 (C.A. 1st, 1919); Bragg v. Farrell, 36 F. 2d 845 (C.A. 2d, 1929); Dewey v. Mimex, 124 F. 2d 986 (C.A. 2d, 1942); Chicago Lock v. Tratsch, 72 F. 2 d 482 (C.A. 7th, 1934); Delta v. Essley, 153 F. 2d 905 (C.A. 7th, 1946); Wisconsin-Minnesota Gas \& Elec. Household Appliance Co. v. Hirschy, 28 F. 2 d 838 (C.A. 8th, 1928). These cases maintaining the "contra" opinion are all traceable to Bates v. Coe, 98 U.S. 31, 48 (1879), wherein the Supreme Court announced that a charge of "infringement"-actually in issue was validity - cannot be avoided by "alleging or proving that a part of the entire thing is found in one prior art patent or printed publication or machine, and another part in another prior exhibit, and still another part in a third one." What the Supreme Court meant was that the charge can be voided only by further proof that new results are lacking. See, e.g., Textile v. Hirsch, 302 U.S. 490 (1937). 
Until recently the matter of experimentation was equally outstanding; correction had to be applied, and was applied, to the overly lenient views of some courts, not of the Patent Office. If the patented invention had been developed from the prior art by experimentation, no matter how slight, this was sufficient to provoke a judicial finding of "invention." In the Second Circuit this view prevailed until twenty years ago; in the Seventh until very recently. ${ }^{82}$ In the Patent Office, the patents in question had usually been allowed only because certain prior art references, such as industrial use or copending patent applications of competitors, were unknown or unavailable for citation; the necessity of experimentation would not have saved these cases, or at least not all of them.

A further example is furnished by the rather frequent cases where an attempt is made to obtain or sustain a patent by mere evidence of commercial success or social impact or the like. The Patent Office, which deals with ingenious men and ingenious thoughts as a matter of routine, is rather immune to such evidence; it insists on technological proof. The courts, which deal more often with bankrupt debtors, violators of regulations and similar individuals, are more easily impressed by generalities about whole industries revolutionized. Even the keen insight of Judge Learned Hand has been blurred.

In one important phase of the invention problem, however, the Patent Office is avowedly more lenient than the courts at least generally are. The Office does not investigate the problem of invention to an impartial solution. If the applicant can show that the matter is at least in doubt, the Office gives the benefit of doubt to him, subject to judicial review. Exceptions to this rule prevailed only under a very few of the Commissioners of Patents.

The rule operates tolerably well so long as the phrase "subject to judicial review" is taken seriously. This, however, has not always been the case; a fact which cannot be blamed on the Patent Office. Courts have sometimes refused to apply this review, in view of an assumed presumption of complete validity, arising from an assumed complete examination of all prerequisites. ${ }^{83}$ Obviously, this was and is improper.

Even if such gratuitous assumptions are avoided, the problem of the benefit of doubt rule is thorny. The existence of at least a doubt about in-

\footnotetext{
82 DuPont de Nemours \& Co., 67 F. 2d 393 (C.A. 2d, 1933); Ruben Condenser Co. v. Aerovox Corp., 77 F. 2d 266 (C.A. 2d, 1935), modifying 85 F. 2d 537 (1936); Wallace v. F. W. Woolworth Co., 133 F. 2d 763 (C.A. 2d, 1943); Wallace v. Mandel Bros., 164 F. 2d 861 (C.A. 7th, 1947), rev'd, 335 U.S. 291 (1948).
}

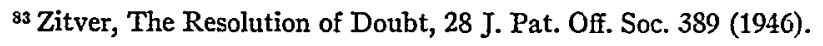


vention can often be conjured up, without real justification, by the submission of ex parte proof in form of affidavits, mainly affidavits about alleged new results. The Examiner may suspect that the facts averred are strongly colored; however, the prevailing rule instructs him to take the ex parte proofs at face value. The patent is then issued, with claims formulated by the applicant and with a record of Patent Office proceedings which is necessarily concise in all respects, and inherently imperfect so far as it relates to matters of doubt, and their significance for the allowed claims. When the patent is subsequently brought into court, it should not and perhaps would not be taken as final so far as it is based on allegations accepted only under the rule of benefit of doubt. However it is practically impossible for a court to review the highly technical decisions of the Patent Office when the record is additionally encumbered with the question whether and to what extent the Office has decided, or merely passed the decision to the court. The relative frequency of invalidity holdings is due to this situation more than to the alleged, relative lowness of invention standards applied by the Office.

In other words, our present patent system, in effect since 1836, provides no complete examination. It stops at the point where positive, factual grounds of invention enter each individual case. It deals with alleged new inventions, but examines only the question whether they are new, and the more superficial part of the question whether they are inventions. It has developed adequate tests of invention, but fails to apply them in cases of doubt.

These failures of course are in addition to other and more inherent shortcomings which introduce human errors even into the positive actions of the Office; for instance, failures to discover prior art anticipations, which affect the question of basic novelty, not only that of invention. Such errors are practically unavoidable, in a certain percentage of administrative actions, and are properly left to discovery by courts either in infringement actions or in suits for declaratory judgment of invalidity. The other type of error, however, is not inherent; it rests on an incompleteness of the examination system supposedly in effect.

I do not wish to imply that this incompleteness can properly be blamed on the Patent Office. Filling the gap involves the performance of independent laboratory tests, field tests, design analyses and test interpretations either technical, economical or legal; and in the typical "new result" problem, most or all of these operations would be involved. All this is apt to come up in practically any of the seventy divisions of the Office, in connection with any of the countless industries presently functioning or newly 
developed. The present Office has neither staff nor budget for such operations. The fact that it has neither staff nor budget for these purposes, and that it therefore furnishes only a partial examination, seems basically due to national stinginess. While the facilities required for a complete correction of the matter would be substantial, they would not be prohibitive, as compared with various other operations of our government.

\section{Proposed Legislation}

It is obvious from the foregoing comments that greater power and responsibility in the Patent Office seems desirable, and that it seems to be the most desirable improvement to be applied to our system if the conflict between the Office and the courts is to be eliminated or at least limited to a reasonable area of disagreement. Indeed, such a development of the stature of the Office has been proposed from time to time, and not only by the Office itself. Perhaps, in fact, the Office has not gone as far as outsiders have, in asking for new powers and responsibilities.

Robert $\mathrm{E}$. Wilson said in 1943, in an address that he delivered when he received the Perkins Medal for some of his research relating to oil:

It must be conceded that a large number of patents . . . do not cover true inventions. While these weak patents are being consistently knocked down by the courts, they are often a source of harassment, confusion and expense... [T] to resolve its doubts in favor of the inventor... . There is ... room for improvement in the information available to examiners. ${ }^{84}$

The idea that there is room for such improvement should be reiterated and urged, and it should be emphasized how central the significance of such improvement is in connection with our painful problem of inventive standards.

This is being overlooked too often. It is being overlooked mainly in those current proposals which are more extreme in character, but also in many of those which favor some middle ground.

The extremists on one side would abolish the issuance of patents by the federal government. ${ }^{85}$ Such an experiment was made in the Netherlands during the last century. It had deplorable results and was soon discontinued. ${ }^{86}$ In this country, most of the states would probably start before

${ }^{84}$ Research and Patents, 25 J. Pat. Off. Soc. 239, 255 (1943); similarly, Nat'l Ass'n of Mfrs., as cited by Folk, Patents and Industrial Progress 46 (1946); Wiley, Public Welfare and Public Policy in the Field of Patents, 29 J. Pat. Off. Soc. 312 (1947); Davis, Proposed Modifications in the Patent System, 12 Law \& Contemp. Prob. 796 (1947).

${ }^{85}$ E.g., Gilfillan, Invention in the History of the Ship, 12 J. Pat. Off. Soc. 341 (1930); Social Principles of Invention, 17 J. Pat. Off. Soc. 216 (1935); Invention as a Factor in Economic History, 29 J. Pat. Off. Soc. 262 (1947); Petro, Patents: Judicial Developments and Legislative Proposals, 12 Univ. Chi. L. Rev. 352 (1945).

${ }^{86}$ Doorman, Patent Law in the Netherlands, 30 J. Pat. Off. Soc. 106 (1952). 
long to enact more or less uniform patent laws. The resulting system, or chaos, would be no improvement over the existing system, least of all for the small business man. An attempt by Congress to eliminate even such a system would amount to unconstitutional abrogation of due process. In spite of judicial dicta to the opposite effect, the Constitution presupposes and secures intellectual property of inventors. ${ }^{87}$

The extremists on the other side would abolish the requirement of invention, either in the Patent Office alone or both there and in the courts. ${ }^{88}$ Abolishment in the Patent Office alone would imitate a highly illogical system that has long existed in modern England, with an administrative examination less complete than ours. In this country this would lead to greater trouble than we have now. Substantive abolishment of the entire requirement of invention would lead to patents for anything barely new, whether obvious or unobvious. Such a system would be too similar to the situation which prevailed during the patent scandals under Elizabeth I to be taken seriously.

Between the extremists there were for a long time those who simply denied or disregarded the problem. Until the Flash of Genius case the patent profession leaned to that view. This general attitude may have served a useful purpose, since it practically eliminated purported reforms, then proposed, which were based on the medieval concept of general compulsory licensing of patents. Until about ten years ago those purported reforms-which actually would harm small business more than the present system does-monopolized the attention of lawyers and legislators. ${ }^{89}$

${ }^{87}$ Industrial property rights of manufacturers and merchants (trade marks) are universally based on common law; see, e.g., Schechter, Historical Foundations of the Law Relating to Trade Marks (1925). Intellectual property rights of authors (copyrights) existed also at common law and were limited rather than created by statute; see mainly Miller v. Taylor, 4 Burr. 2303 (1769), and Donaldson v. Becket, 4 Burr. 2404 (1774). These are explained and restated by Rogers, A Chapter in the History of Literary Property, 5 III. L. Rev. 551 (1911). As to the intellectual property rights of inventors (patents and the earlier so-called privileges), it was generally assumed until recently that the historic background was different, and that no such rights existed except by grant of a sovereign, king or Parliament. This assumption explains the dicta about nonexistence of common-law exclusive rights in inventions. These dicta occur mainly in Gailer v. Wilder, 10 How. (U.S.) 477 (1850). As to some limited issues, these dicta have led to actual holdings, e.g., Marsh v. Nichols, 128 U.S. 605 (1888). Others have insisted that these dicta "must be wrong." Indeed the assumption on which these dicta were based seems erroneous; see my articles, A History of Intellectual Property from 1545 to 1787, $26 \mathrm{~J}$. Pat. Off. Soc. 711 (1944), and The Early Growth and Influence of Intellectual Property, $34 \mathrm{~J}$. Pat. Off. Soc. 106 (1952).

${ }^{88}$ E.g., Cooper and Fox, op. cit. supra note 10; also, conditionally, Patent Policy and Invention, 46 Ill. L. Rev. 609,625 (1951). The condition suggested in that Comment is "a related narrowing of the use to which a patent could be put." This seems to suggest compulsory licensing. The concept of a "related narrowing" is based on the notion that Congress can simply parcel out patent benefits according to some preferred, arbitrary plan.

${ }^{89}$ For the early hearings, consult Vaughan, Economics of Our Patent System (1925). For the post-depression hearings, consult Report of the Committee on the Relation of the Patent 
Since the Flash of Genius case, however, it has become increasingly clear that a more central issue of patent law requires legislative clarification..$^{90}$ For some more years, well-wishing writers believed that there was no real conflict. ${ }^{91}$ More recently, the reality of the conflict has scarcely been denied..$^{92}$

Several bills were introduced in Congress to correct the flash of genius doctrine or confusion..$^{93}$ The constitutionality of this procedure has been questioned once..$^{94}$ However, it is likely to be upheld. ${ }^{95}$ This applies at least if the proposed statute really clarifies the issue by proper elaboration upon the generalized terms of the Constitution..$^{96}$

Meanwhile the original bills against the flash of genius doctrine have been expanded in scope. They now recodify the entire body of patent law, except the administrative and budgetary standing of the Office. Such a proposal is now before Congress, and is expected to become law on January 1,1953 . It is known as the Bryson Bill. ${ }^{97}$ The following standard of patentability is proposed in Section 103 of this bill:

System to the Stimulation of New Industries, 18 J. Pat. Off. Soc. 94 (1936); Final Report and Recommendations of the Temporary Nat'l Economic Committee on the Investigation of Concentration of Economic Power, 23 J. Pat. Off. Soc. 383 (1941); Report of the Nat'l Patent Planning Commission, 25 J. Pat. Off. Soc. 455 (1943); Third Report of the Nat'l Patent Planning Commission, 27 J. Pat. Off. Soc. 579 (1945).

${ }^{90}$ Consult The American Patent System-Report of the Nat'l Patent Planning Commission to the President, 25 J. Pat. Off. Soc. 463 (1943).

${ }^{91}$ Consult Nielsen, Flash of Genius, 24 J. Pat. Off. Soc. 371 (1942); Allyn, Patentable Yardsticks, 25 J. Pat. Off. Soc. 791 (1943); Spintman, Has the Standard of Invention Been Raised?, 27 J. Pat. Off. Soc. 422 (1945).

${ }^{92}$ See, e.g., Ooms, What Shall Be Done To Make Our Patent Office More Effective . . . ?, 28 J. Pat. Off. Soc. 5 (1946); Rich, "Patentable" Inventions, 28 J. Pat. Off. Soc. 583 (1946); Posnak, The Baffled Judiciary, 31 J. Pat. Off. Soc. 168 (1949); Weklind, No Valid Patents?, 31 J. Pat. Off. Soc. 859 (1949).

${ }^{93}$ H.R. No. 3694, 79th Cong. 1st Sess. (1945); H.R. No. 5248, 80th Cong. 2d Sess. (1948).

24 Kenyon, Why Challenge the Court's View of "Invention"?, 35 A.B.A.J. 480 (1949).

${ }^{9} \mathrm{Mr}$. Kenyon's argument is that Congress cannot force the Court to interpret the Constitution one way or another. However, the constitutional terms "inventors" and "discoveries" allow legislative elaboration at least as well as judicial interpretation. They are not vague or conflicting, only broad and generalized.

${ }^{96}$ In principle the constitutional question of our inventive standard is a question of proper delegation of power. Historically, patents were granted by individual, legislative acts. The Constitution contemplates patents granted by Congress, not patent laws enacted by Congress. In enacting any patent laws, Congress used and uses an inherent power of delegation. It delegates its functions to a purely administrative agency. Ever since 1790, such delegations had been vague and unregulated as to the point of "invention." Will they be regulated now?

${ }_{27}$ H.R. No. 7794, 82d Cong. 2d Sess. (1952). This was preceded, in basically similar form, by H.R. No. 3760, 82d Cong. 1st.Sess. (1951); H.R. No. 9133, 81st Cong. 2d Sess. (1950). Revisions had been sponsored by the Coordinating Committee of the Nat'l Council of Patent Iaw Ass'ns, Proposed Revision and Amendment of the Patent Laws (1950). Subsequent to the writing of this article the bill was enacted and signed. 
A patent may not be obtained though the invention is not identically disclosed or described . . . as set forth in section 102 of this title, ${ }^{98}$ if the differences between the subject matter sought to be patented and the prior art are such that the subject matter as a whole would have been obvious at the time the invention was made to a person having ordinary skill in the art to which said subject matter pertains.

Patentability shall not be negatived by the manner in which the invention was made.

Whether this act will be held constitutional remains to be seen. With regard to the term "invention" the provision seems based on the historic theory of Cooper and Fox. The existing statute speaks more clearly of "alleged" invention.

When sustained and enforced the Bryson Bill is capable of lowering patent standards not only in the courts but also in the Patent Office.

The continued reliance on words like genius or unobviousness seems fruitless. The term "new and ingenious" no doubt was adequate in 1474, but the bare word "discovery," used in 1789, had to be explained by a long, laborious and not all together successful process of judicial interpretation. Conflicts between past decisions will not be eliminated by a new magical formula like the test whether "the subject matter as a whole would have been obvious." In spite of the opposition of a minority of judges it would be more constructive to set forth detailed and historically accepted rules of invention. ${ }^{99}$ If these rules are set forth in proper phraseology, as known from numerous decisions and text books, they certainly furnish more light than does a single, abbreviated slogan.

Still more success could be expected from a statute that also puts an end to our national stinginess in Patent Office matters. A system of full patent examination should be established. This would lead to strong and confidence-inspiring patents. It may even be predicted that it would lead to a new rise in our per capita figures of invention and industrial improvement.

${ }^{98}$ Referring to prior patents, prior publications, etc.

${ }^{99}$ See also the Recommendations of the Nat'l Ass'n Mfrs., 8 Nat'l Ass'n Mfrs. (Dec. 1945); Folk, op. cit. supra note 84, at 45; similarly, Pitt, Patent Law "Invention," 34 Cornell L.Q. 663 (1949). 